\title{
Service landscape for private universities in Indonesia based on service oriented architecture and cloud technology
}

\author{
Faiza Renaldi, Irma Santikarama, Esmeralda C. Djamal, Agya Java Maulidin
}

Department of Informatics, Faculty of Science and Informatics, Universitas Jenderal Achmad Yani, Cimahi, West Java, Indonesia

\begin{tabular}{l} 
Article Info \\
\hline Article history: \\
Received Mar 12, 2020 \\
Revised Dec 5, 2020 \\
Accepted Jan 13, 2021 \\
\hline Keywords: \\
Academic processes \\
Cloud technology \\
Design science research \\
Higher education technology \\
Integration and flexibility \\
Service landscape \\
Service-oriented architecture
\end{tabular}

Corresponding Author:

Faiza Renaldi

Department of Informatics, Faculty of Science and Informatics

Universitas Jenderal Achmad Yani

Jl. Ters. Jend. Sudirman, Cimahi, Indonesia

Email: faiza.renaldi@unjani.ac.id

\begin{abstract}
Information technology (IT) has been widely adopted and is believed to improve academic processes' efficiency and run private universities' academic functions (PTSs) in Indonesia. Nonetheless, adopting diverse technologies for them will also create many challenges. PTSs are struggling to survive in terms of technological implementation, in the sense that the investment and implementation rate in the PTSs just cannot catch up with the technological advancement rate. Even when more PTSs are trying to transform into digital entities, the next problem will be system integration and flexibility. This study aims to overcome this problem by implementing a framework that can be both integrated and flexible while also serving the efficiency of investments. Many studies already suggested that service oriented architecture (SOA) and cloud technology are the solutions. Nevertheless, none has been able to define what standard services can be applied within those platforms. To determine this, we use the BIAN service landscape, which was translated from the banking industry, offering a comprehensive view of the business domain and business capabilities alongside its service functions. While BIAN offers common services throughout the same platform, we modify the framework using the OASIS model from SOA, which allows the framework to be flexible in complying with many platforms of databases, programming languages, and network infrastructures. We completed our study by defining one business area: academic processes, three business domains, 19 business capabilities, and 84 service functions. We are strongly confident that our findings and study results will act as a reference in creating a cloud-based platform for Indonesia's higher education academic systems.
\end{abstract}

This is an open access article under the CC BY-SA license.

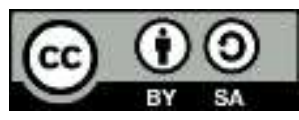

\section{INTRODUCTION}

Information technology (IT) has been widely adopted and is believed to improve academic processes' efficiency and run private universities' academic functions (PTSs). They are expected to continually develop and implement systems that will provide them with appropriate functions to communicate with their stakeholders, mainly the students [1]. Academic processes have been intensively based on technology; it shifts how students-lecturer interact in the classroom using ubiquitous computing devices [2], monitoring students' academic progress using big data and data warehouse [3]. Such intense is 
not only done in western countries [4], but also in developing ones such as Saudi Arabia [5] and Thailand [6], and also in Indonesia [7]. One research conducted in Kepulauan Riau, Indonesia, showed that students are getting more engaged in lecture activities and will finally give a satisfactory appraisal of the competitive advantage for that private university.

All of those mentioned above have created the term technology-enhanced learning (TEL), which refers to the benefit of utilizing information and communication technologies in learning and teaching. The term goes back to 15 years ago [8] and usually incorporates other terminologies such as electronic learning (e-learning), LMS, and mobile learning (m-learning). Many of them are starting to add features of virtual classrooms via online learning and video conferencing. Cloud servers allow institutions to offer these innovative teaching methods that students can access anywhere via tablets, computers, or mobile devices. Nonetheless, adopting diverse technologies for them will also create many challenges. In Indonesia, the number of PTSs (around 3,000) is far higher than the state universities (122 universities) [9]. It is estimated that out of 6.9 million Indonesian students, $68 \%$ of them (4.7 million) are studying in PTSs. PTSs have increased higher education access to society amid the limited capacity of state campuses. This will require an excellent academic system, and obtaining one that provides benefits for a particular PTS is undoubtedly not without obstacles. Major obstacles that the campus often faces include the amount of investment needed, the quality of staff, IT infrastructure, and system compatibility with existing business processes [10].

Big (funded) PTSs are making advancements in their systems, and lesser (funded) PTSs struggle to survive technological implementation. Back then, the investment and implementation rate in the lesser PTSs just cannot catch up with the technological advancement rate [11]. Even when, nowadays, more and more PTSs are trying to transform into digital entities [12], the next problem will come integration and flexibility [6]. Modular IT implementation will inevitably lead to disintegration and inflexibility, and it will become a chaotic environment when more systems are implemented [13]. PTSs need to have those problems solved because of the ever-fast changes of technologies and government regulation regarding PTSs academic, operational activities that also keep changing. Each system within the higher education ecosystems can be changed without affecting other sub-systems; the service can be distributed and available to every request without being limited by the database technologies, programming language, or other technological platforms [14]. One research suggested having integrated systems between private universities, not only within each university [15]. service-oriented architecture (SOA) is an IT solution in terms of integration and flexibility and can be done in stages. SOA has become an architectural model widely used in providing service-based architecture solutions or services [16]. Moreover, it is also a reusable model that can use a service that has been provided without having to create a new design for the same service. What most importantly, it is an architectural framework that provides flexibility for organizations. Scalable cloud storage offers PTSs the ability to expand storage capabilities quickly. All of those means cheaper cost [17]. Cheaper costs in IT can only be applied to shared resources, and shared resources mean cloud paradigm [18]. Due to the prevailing financial issue and at some PTSs also facing the growing needs for a good and reliable academic system, the cloud environment can salvage PTSs from those two issues. It is a chance for them to exploit the opportunities afforded by cloud technology while minimizing the associated security risks to allow access to advanced IT infrastructure, data centers, and applications and protect sensitive information [19].

Many studies have dealt with the technical issue on how to develop a good platform using SOA architecture, and cloud-based platform in the education sector [20], especially the higher ones [21-22], but lesser have dealt within the application level, which discussed the kind of services that can be created to be commonly enjoyed by universities. They were limiting their scope to only one specific university [23-25]. While working with SOA and cloud platforms, we can have high commonalities in share functions. Our initial investigation suggests that the service landscape can facilitate this issue. This approach can expedite SOA analysis with the academic process modeling domain business and service capability [26]. Service Landscape can show capabilities that should be owned by a service layer that can support a typical organization's business processes. The service landscape was firstly introduced by banking industrial architecture network (BIAN) and issued Service Landscape for the banking sector called BIAN Service Landscape. It is an example of standardization in mapping business domains and their capabilities, which can support business processes in the banking sector, as they need a very high standardization level amongst one bank to another. It is also defined as a frame of reference that categorizes and organizes the BIAN Service Domain for easy access. Domain service is used to define service operations offered by the BIAN Service Domain to model their banking process technologically [27]. By using the BIAN Service Landscape, banking companies can quickly analyze the capability of service that must be built to support business activities. Therefore, we believe by designing this study using an SOA, Service Landscape approach, and cloud-based platform, we will be able to create a framework of common service domain and functions for every PTSs at their disposal. 


\section{RESEARCH METHOD}

In designing the service landscape PTSs, we use the design science research methodology process model [28], customized and adapted to our study stages. Our study begins with identifying the problem and motivation, continued to the next stage of defining goals and solutions, design and development, review, and lastly, communicating our findings. Throughout this study, we performed a data collection activity consisting of interviews and observations. We were fortunate to have acquired eight private universities in Bandung, Indonesia, that are willing to be interviewed and observed (under anonymity) on their academic systems' current position. The interview processes took place at each PTSs, on August 13 until 15, 2019; next on September 3 until six and September 17-18, 2019; October 3 to 5, 2019; and lastly on November 15, 2020. Each interview took an average of 2 hours. At each meeting, we highlighted different topics such as the business process; organization profile with their structure, vision, and mission; problems or needs within the processes that need to be addressed; and actors, their role in the processes, and specifically defined the information flow between each actor across the processes. Besides interviews, we also conduct observations simultaneously on the 3rd and fourth week of November 2019. This event highlighted more findings that were not mentioned by the interviewees earlier. We recorded and summarized our findings and validated them to the interviewees before deciding to put them all as research facts.

\subsection{Identifying the Problem and Motivation}

As described earlier, we can identify two problems that we would like to elucidate; number one is integration and flexibility, while the second one is efficiency. When PTSs using technology to support its academic activities, it must be integrated with high flexibility to generate a flow of information from the beginning of academic processes (student registration) until the end (graduation). This flow is defined as the business area within our scope of the study. To a greater extent, we also found that since PTSs mostly work on a very tight budget, it requires them to select the technologies (cost-effective) carefully. The SOA-based solution is in demand for the first reason, while the second reason suits the cloud architecture. SOA can be applied as a web service that performs the service's function to be consumed by other system parts. We map the level of priority between 3 problems that have been identified earlier during our data collection process and are depicted in Table 1.

Table 1. Problems Priorities between Respondents

\begin{tabular}{cccccccccc}
\hline $\begin{array}{c}\text { Samples } \\
\text { Criteria }\end{array}$ & PTS1 & PTS2 & PTS3 & PTS4 & PTS5 & PTS6 & PTS7 & PTS8 \\
\hline Integration & 1 & 2 & 2 & 3 & 1 & 1 & 3 & 3 \\
Flexibility & 2 & 3 & 3 & 2 & 2 & 2 & 2 & 1 \\
Efficiency & 3 & 1 & 1 & 1 & 3 & 3 & 1 & 2 \\
\hline
\end{tabular}

The number 1 until 3 defines priority levels, where the lower the number means, the higher the priority. Interestingly, integration scored 16, flexibility scored 17 , and efficiency scored 15 . This result shows that the three problems are equally important to solve. Motivation is defined to trigger the problem-solving effect, allows PTSs (even smaller ones) to enjoy the benefit of technology for their academic processes. We model SOA and cloud-based platforms to be able to interact with the service landscape seamlessly. SOA acts as middleware, and the cloud platform will handle the reusability model.

\subsection{Defining Goals and Solutions}

Defined by previous researches, Our goal is to have a cloud-based architecture of academic processes for PTSs which assured to have a very great extent of integration $[6,13]$, flexibility [6, 14-16], and efficiency [17-19]. Nevertheless, the next question is, what should we put inside the system? This will be answered when we define goals and solutions. Based on the results of the identification of the problem, the solution offered is to develop a service landscape of PTSs integrated systems. Service landscape generated should cover all academic processes. SOA-based architecture and cloud platform will provide the working environment below the service landscape of academic processes.

\subsection{Design and Development}

We design a landscape of services by doing interviews and look at the integrated systems in various PTSs. The service landscape can be constructed by performing a thorough analysis of academic processes and services. We then categorize candidates resulting from this analysis capabilities into groups (up-down approach). The service analysis and identification are made using SOA analysis to produce business domains and service capabilities contained therein. The service landscape consists of 3 main elements: the business 
area, business domain, and service domain [29]. We have defined our business area in the earlier section (2.1) as academic processes and services starting from new student registration until graduation management. The next action is to determine the business domain and service domain. We use a customized BIAN approach with the SOA-based OASIS model [30]. OASIS is famous for its flexibility in modeling since it is a reference model. A reference model is not directly tied to any standards, technologies, or other concrete implementation details. It does seek to provide a standard semantics that can be used unambiguously across and between different implementations. It will understand significant entities within the academic processes and relationships between them within a service-oriented environment.

\subsubsection{Requirements}

It is used to collect all necessary data of the academic processes included in service landscape. We divide these processes into main academic processes and supporting academic processes. Also, we carried out an analysis of the role of IT academic systems in the PTSs. The analysis result is a checklist requirement and will be treated as a reference later in the review stage. We extract from online surveys, interviews, and observations, 27 academic processes involved and will be included in this service landscape. The depicted systems checklist, as shown in Table 2.

Table 2. Academic Processes took from 8 PTSs

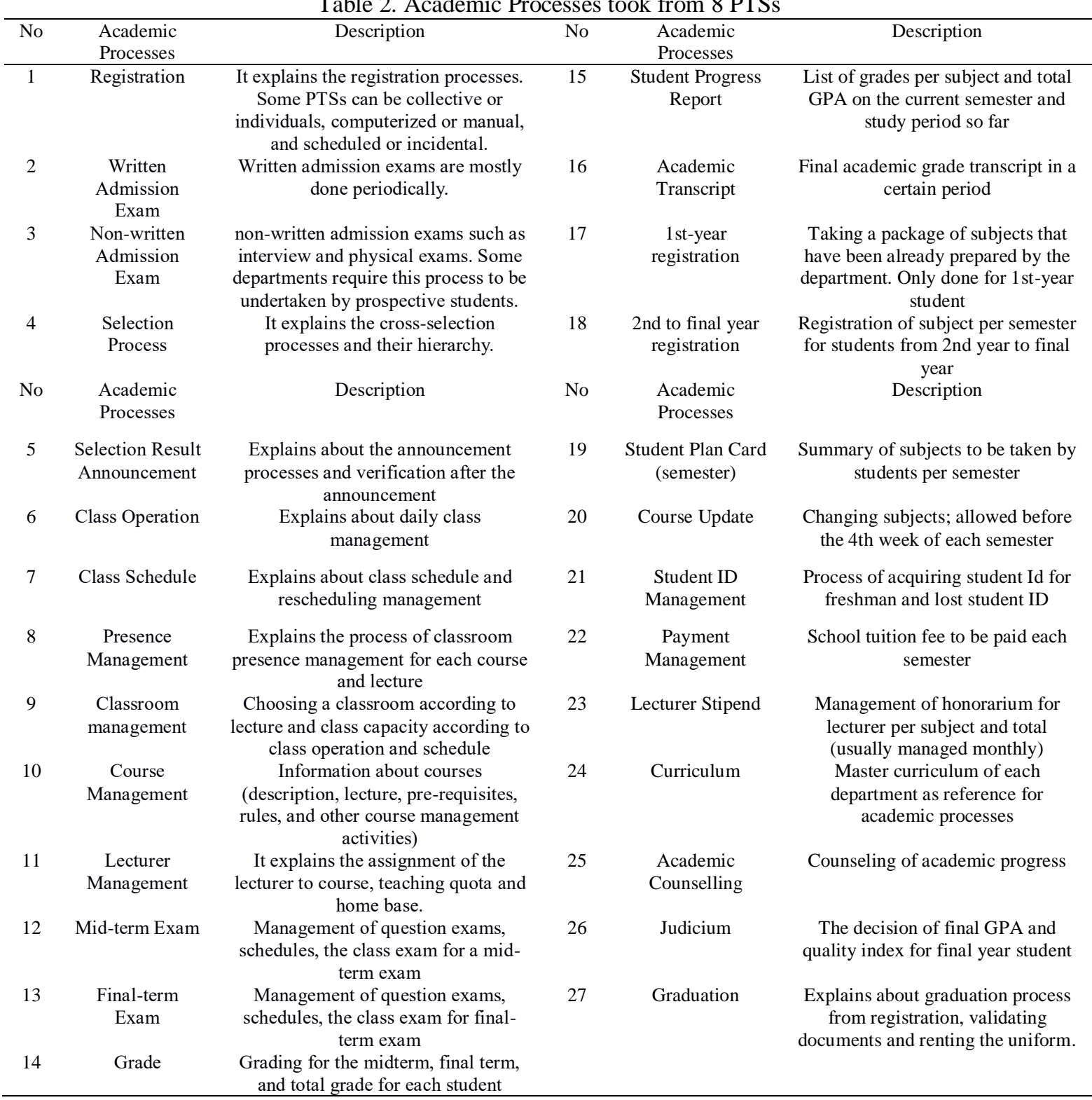


This process is done with a questionnaire machine software and one-on-one interviews with the system's stakeholders from our respondents of 8 PTSs. These 27 academic processes will then be crossreferenced in later stages to generate standard capabilities to be used by every PTSs. Some processes are standard, while some are not; we only take the common ones to create the service landscape in the design and review stages later. An example of this stage's result is depicted in Figure 1.

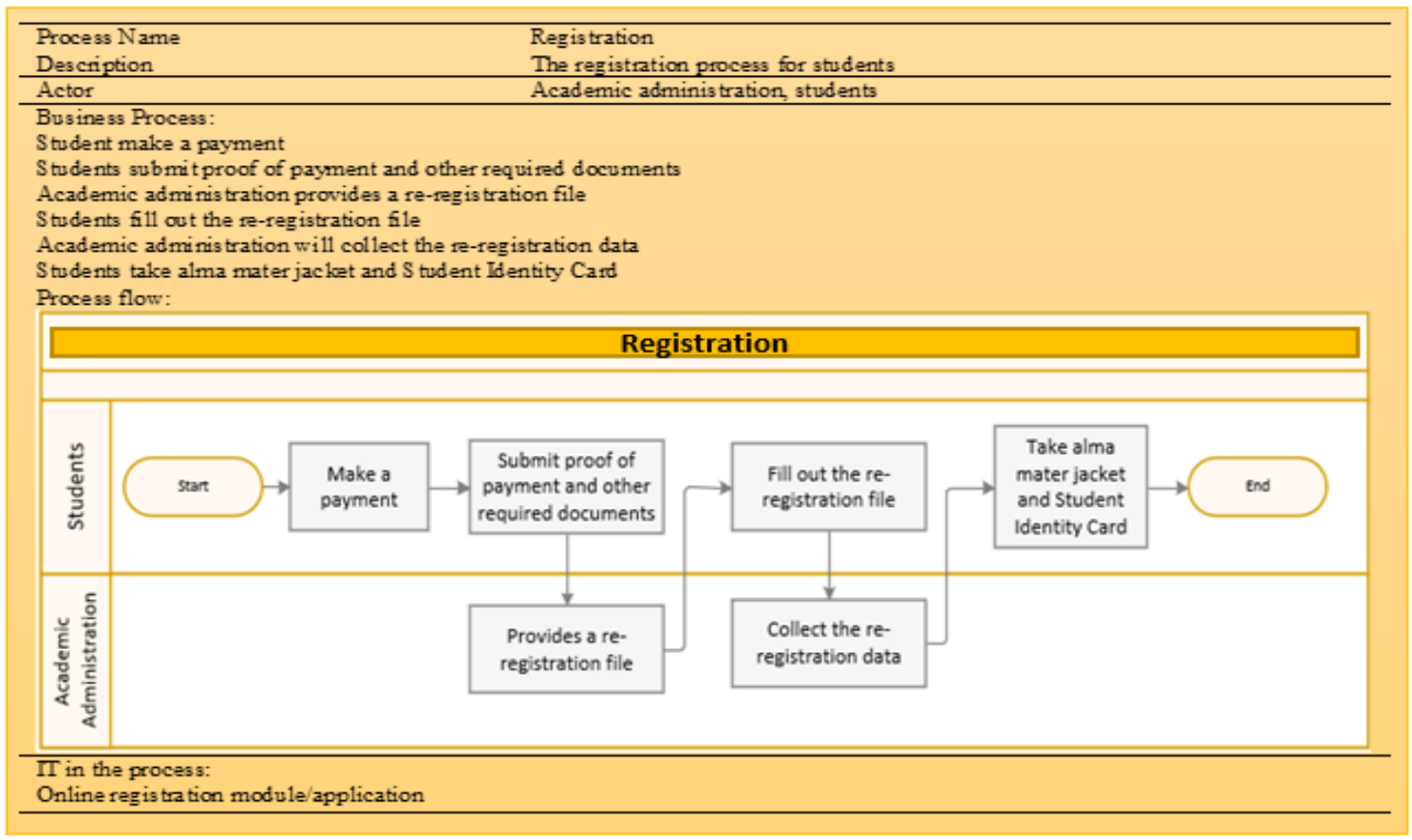

Figure 1. Registration Process

\subsubsection{The analysis}

It analyzes academic process services using OASIS methodology to result in the business domain and business capabilities. Information taken from the requirement stage will be processed into several domains, such as follows:

a) Analysis of business domain

The business domain was decided by analyzing the academic processes that happened within our respondents. While each business domain represents its independence, it is interconnected to create seamless academic processes [31]. Domain analysis performed in previous stages is yielding three business domains, which are (1) Admission of new students, (2) Teaching and Learning Process, and (3) Academic administration. Some namings are different from one PTS to another PTS, but all refer to the same meaning.

b) Analysis of business capabilities

First, we determine candidates of services built from one academic process (business capabilities), as shown in Table 3. Each business capability that has been defined earlier on the requirement stage will be analyzed one by one, just like what we did in Table 3 . We cross-referenced our findings from all our respondents and trimmed down the business capabilities from 27 processes in the requirement stage into 19 that is common to each PTSs, as shown in Table 4.

c) Analysis of SOA and Cloud Technology

Integration can be done by providing information from academic processes as services, using SOA principles (flexible, sustainable, reusable integration) and instruments to plot academic processes' variables [32]. The integration of SOA with academic processes possibly will pilot the creation and use of new learning settings. This condition requires the latest software and hardware required to meet the institution's demands and high costs. Cloud Computing helps organizations like private universities by offering cloudmaintained solutions and better software, hardware, and maintenance [33]. Also, mobile instruments such as laptops, phones, and tablets provide remote access to resources available [34]. We determine SOA and cloud technology preferences by interviewing our respondents, as shown in Table 5. 
Table 3. Business Capabilities and Service Functions

\begin{tabular}{|c|c|c|}
\hline No & Business Capabilities & Service Functions \\
\hline 1 & Registration & +insertDataPendaftaran(), +setDataPendaftaran() \\
\hline 2 & Written Admission Exam & +getDataPendaftaran(), +createDataUjianSeleksi() \\
\hline 3 & Non-written Admission Exam & +getDataPendaftaran(), +createDataUjianSeleksi() \\
\hline 4 & Selection Process & +getDataUjianSeleksi(), +createDataSeleksi(), +editDataSeleksi() \\
\hline 5 & Selection Result Announcement & +getDataSeleksi() \\
\hline 6 & Class Operation & $\begin{array}{c}\text { +setDataKUliah(), +getDataKuliah }(),+ \text { createDataKuliah( }), \\
\text { +editDataKUliah(), } \\
\text { getDataJadual }(),+ \text { getDataMahasiswa }(),+ \text { getDataDosen }(), \\
+ \text { getDataMK }(),+ \text { getDataAbsensi }()\end{array}$ \\
\hline 7 & Class Schedule & $\begin{array}{c}+ \text { setDataJadual }(),+ \text { getDataJadual }(),+ \text { getDataMahasiswa }(),+ \text { getDataDosen }(), \\
+ \text { getDataMK }(),+ \text { getDataAbsensi }()\end{array}$ \\
\hline 8 & Presence Management & $\begin{array}{c}\text { +setDataAbsensi(), +getDataAbsensi(), +createDataAbsensi(), +editDataAbsensi(), } \\
\text { +getDataMahasiswa(), +getDataDosen }(),+ \text { getDataMK() }\end{array}$ \\
\hline 9 & Classroom management & $\begin{array}{c}\text { +setDataKelas }(),+ \text { getDataKelas }(),+ \text { createDataKelas }(),+ \text { editDataKelas }(), \\
\text { +getDataMK }(),+ \text { getDataDosen }(),+ \text { getDataMahasiswa }()\end{array}$ \\
\hline 10 & Course Management & + setDataMK ()$,+$ getDataMK ()$,+$ createDataMK ()$,+$ editDataMK () \\
\hline 11 & Lecturer Management & $\begin{array}{c}\text { +setDataDosen }(),+ \text { getDataDosen }(),+ \text { createDataDosen }(),+ \text { editDataDosen }(), \\
+ \text { deleteDataDosen }()\end{array}$ \\
\hline 12 & Mid-term Exam & +setDataUTS(), +getDataUTS(), +createDataUTS(), +editDataUTS() \\
\hline 13 & Final-term Exam & +setDataUAS(), +getDataUAS( $),+$ createDataUAS( $),+$ editDataUAS( $)$ \\
\hline 14 & Grade & +setDataNIlai(), + getDataNIlai(), +getDataMataKUiah(), +getDataMahasiswa() \\
\hline 15 & Student Progress Report & + setDataKHS ()$,+$ getDataKHS ()$,+$ getDataNilai ()$,+$ createDataKHS() \\
\hline 16 & Academic Transcript & +setDataTranskrip ()$,+$ getDataTranskrip ()$,+$ getDataKHS( $)$ \\
\hline 17 & 1st year registration & +setDataDaftarUlang ()$,+$ getDataDaftarUlang ()$,+$ createDaftarUlang() \\
\hline 18 & 2nd to final year registration & $\begin{aligned} \text { +getDataMahasiswa }(), & + \text { setDataDaftarUlang }(),+ \text { getDataDaftarUlang }(), \\
& + \text { createDaftarUlang }()\end{aligned}$ \\
\hline 19 & Student Plan Card (semester) & +setDataKRS(), +getDataPKRS, +createDataKRS(), +editDataKRS() \\
\hline 20 & Course Update & +getDataKRS ()$,+$ setDataPKRS(), + getDataPKRS() \\
\hline 21 & Student ID Management & +getDataMahasiswa() \\
\hline 22 & Payment Management & +getDataMahasiswa(), + getDataMataKuliah(), +setPembayanSemester() \\
\hline 23 & Lecturer Stipend & +getDataDosen ()$,+$ setDataHonorDosen ()$,+$ getDataHonorDosen () \\
\hline 24 & Curriculum & $\begin{array}{c}\text { +setDataKurkulum(), +getDataKurikulum(), +createDataKurikulum(), } \\
\text { +editDataKurikulum(), +deleteDataKurikulum() }\end{array}$ \\
\hline 25 & Academic Counselling & $\begin{array}{c}\text { +setDataPerwalian }(),+ \text { getDataPerwalian }(),+ \text { createDataPerwalian }(), \\
\text { +editDataPerwalian }(),+ \text { deleteDataPerwalian }()\end{array}$ \\
\hline 26 & Judicium & +setDataYudisium(),+getDataYudisium () \\
\hline 27 & Graduation & +getDataTranskrip ()$,+$ getDataYudisium ()$,+$ getDataPerwalian () \\
\hline
\end{tabular}

Table 4. Business Domains and Their Business Capabilities

\begin{tabular}{llll}
\hline & BD1: Admission of New Students & BD2: Teaching and Learning Process & BD3: Academic Administration \\
\hline Business & 1) Registration & 1) Class Operation & 1) New Registration \\
Capabilities & 2) Exam & 2) Class Schedule & 2) 2nd-year to final year \\
& 3) Selection Process & 3) Presence Management & registration \\
& 4) Selection Announcement & 4) Classroom Management & 4) Curriculum \\
& 5) Exams & 6) Grades & 5) Academic Counseling \\
& 7) Student's Progress Report & 6) Judicium & 7) Graduation
\end{tabular}

Table 5. Analysis of SOA and Cloud Technology on Academic Processes

\begin{tabular}{cccc}
\hline No & Main Topic & Sub-Topic & Result $(\mathrm{n}=24) *$ \\
\hline 1 & Architecture Preferences & On-Premise only & $3(12.5 \%)$ \\
& & On-the-cloud only & $12(50 \%)$ \\
& & Hybrid (on-premise and on-the-cloud) & $9(37.5 \%)$ \\
2 & Platform preferences & Desktop based only & $0(0 \%)$ \\
& & Web-based only & $3(12.5 \%)$ \\
& & Mobile-based only & $3(12.5 \%)$ \\
3 & Technology & Hybrid (a combination of the three) & $18(75 \%)$ \\
& & API services & $20(83.33 \%)$ \\
& & Microservices & $4(26.67 \%)$ \\
\hline
\end{tabular}

\subsubsection{Review}

It is used to review the service landscape generated using a checklist of academic processes produced on the first stage (requirement). From the beginning of the requirement stage until the design stage, we have defined one business area, three business domains, 27 business capabilities, and 104 service 
functions. After we cross-examined them between PTss within our samples' scope, we decided to use only 19 business capabilities and 84 service functions as depicted in Table 6 .

Table 6. Final Review on the Business domain and Business Capabilities

\begin{tabular}{|c|c|c|c|c|}
\hline No & Business Domain & \# & Business Capabilities & Remarks \\
\hline \multirow[t]{4}{*}{1} & Admission of New Student & 1 & Registration & \\
\hline & & 2 & Exam & Combining written and non-written \\
\hline & & 3 & Selection Process & \\
\hline & & 4 & Selection Announcement & \\
\hline \multirow[t]{8}{*}{2} & Teaching and learning process & 5 & Class operation & \\
\hline & & 6 & Class schedule & \\
\hline & & 7 & Presence management & \\
\hline & & 8 & Classroom management & $\begin{array}{l}\text { Combining with course management. } \\
\text { Classroom as the main primary key }\end{array}$ \\
\hline & & 9 & Exam & Combination of mid-term and final \\
\hline & & 10 & Grade & \\
\hline & & 11 & Student's progress report & \\
\hline & & 12 & Academic transcript & \\
\hline \multirow[t]{7}{*}{3} & Academic administration & 13 & 1st-year registration & $\begin{array}{l}\text { Student plan card, course update, and } \\
\text { student ID are combined here }\end{array}$ \\
\hline & & 14 & 2 nd to final year registration & $\begin{array}{l}\text { Student plan card, course update, and } \\
\text { student ID are combined here }\end{array}$ \\
\hline & & 15 & Finance & $\begin{array}{l}\text { Combination of payment management and } \\
\text { lecturer stipend }\end{array}$ \\
\hline & & 16 & Curriculum & \\
\hline & & 17 & Academic Counselling & \\
\hline & & 18 & Judicium & \\
\hline & & 19 & Graduation & \\
\hline
\end{tabular}

\subsection{Communication}

At this stage, we prepare reports or documentation of this study. Documentation comes in the form of document research reports and guidance documents on the use of Service Landscape.

\section{RESULTS AND ANALYSIS}

The process passed from the stage of requirements until the review, then compiled into a technological service landscape for academic processes in PTSs, as depicted in Figure 2. We completed our framework by resulting in 1 business area of academic processes, three business domains, 19 business capabilities, and 84 service functions out of the initial 27 business capabilities and 104 service functions. We visualized them using one rectangle of service functions inside a rectangle of business capabilities. Several business capabilities join together in a bigger rectangle of the business domain, which then groups into one as a service landscape of academic processes. Each business's capabilities and business domain are independent but integrated, with at least one function interconnects them to one another. For example, admission of new students started from the admission part of inserting registration data (+insertDataPendaftaran()) and validate it using + setDataPendaftaran(). 'Admission' and 'Selection Test' are interconnected using DataPendaftaran() function, and it applies to the other throughout this service landscape. Furthermore, some business capabilities and service functions were merged, as was described earlier in section 2.3.3. Flexibility is also the reason for the rectangle visualization. This result means that each PTS can easily requests which business capabilities or business domain they wish to implement. We also apply SOA and cloud architecture on top of this service landscape, as shown in Figure 3.

When it comes to implementing SOA, there is a wide range of technologies that can be used. Typically, SOA is implemented with web services, making the functional building blocks accessible over standard internet protocols. Our building blocks consist of a platform as a service (PaaS), software as a service (SaaS), SOA, and individual tenants (PTSs). PaaS provides backend services for the provider to maintain the system, including runtime, databases, servers, billing, and more. SaaS is the business domain that we have already identified in the service landscape, consisting of admission of the new student, teaching and learning process system, and academic administration system. For future improvement and expecting changes in business processes, the changes will only be needed to apply part of the ecosystem (SaaS). We can add more business domains, business capabilities, and service functions within the application part to update or add more services for PTSs. 


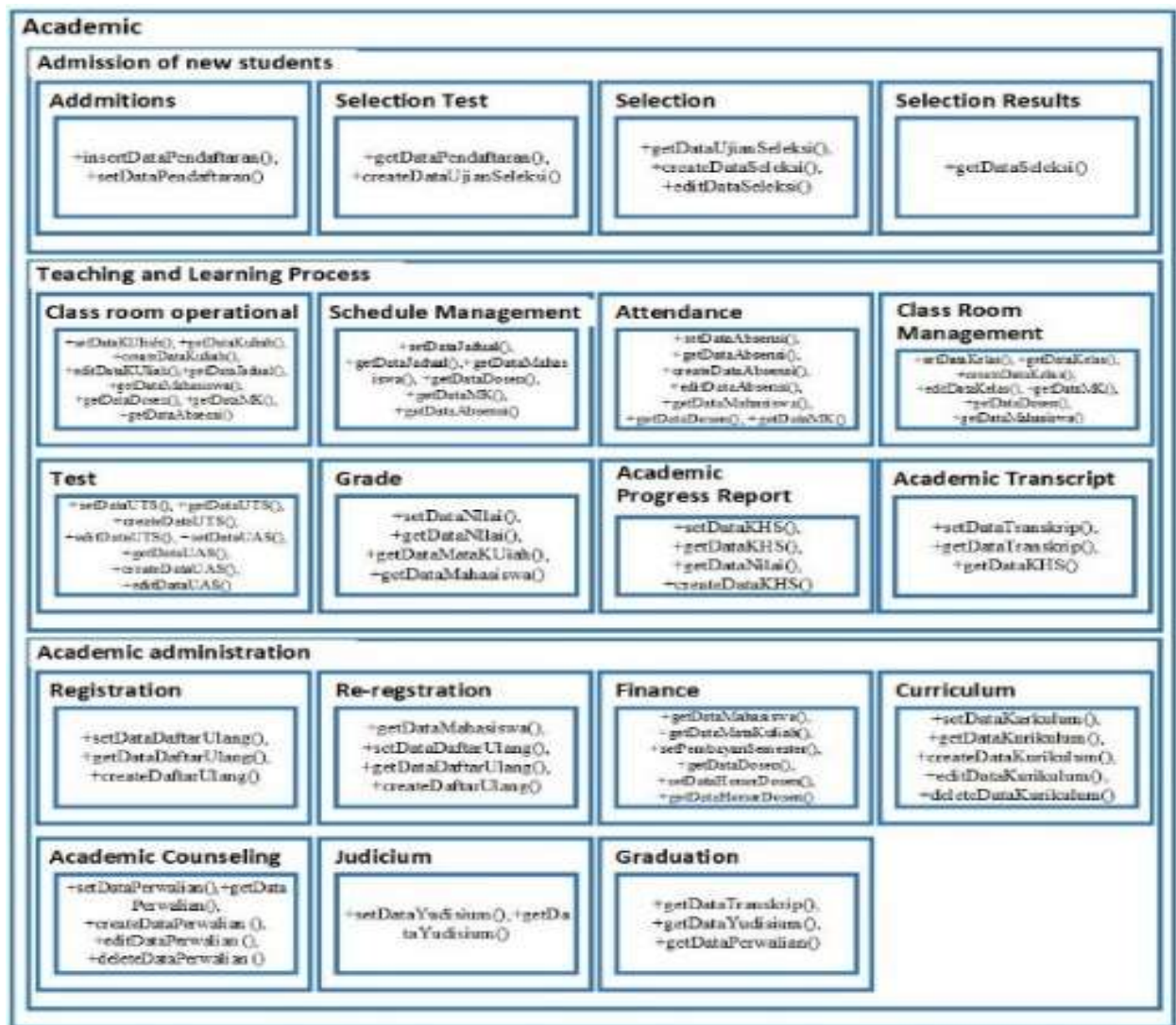

Figure 2. The framework of Technological Service Landscape of Academic Processes in PTSs

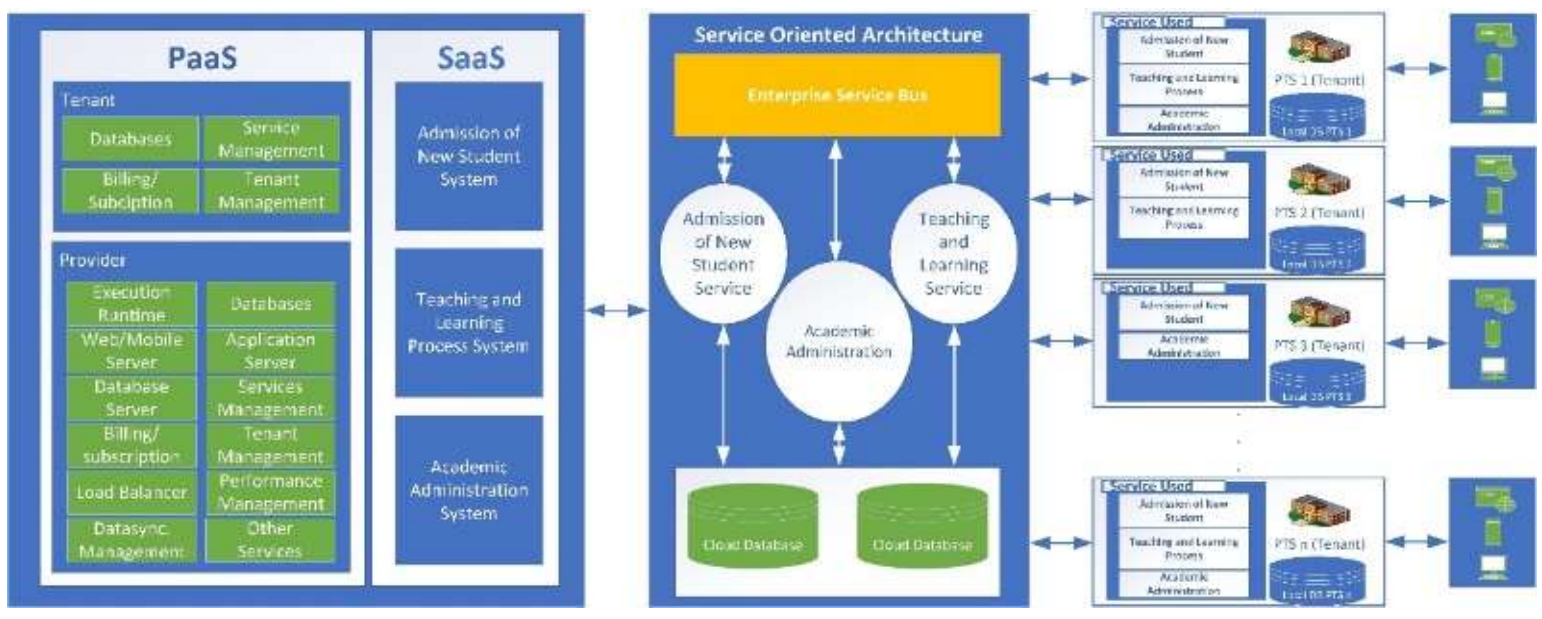

Figure 3. Cloud-Based Platform on Academic Service Landscape Based on SOA

\section{CONCLUSION}

This study results from a service landscape for PTSs' academic processes using SOA as technological architecture. We completed our study by defining one business area: academic processes, three business domains, 19 business capabilities, and 84 service functions. This result will serve as a foundation for PTSs to choose their services within academic systems, which have a strong integration and flexibility. Furthermore, we equip this study with the architecture for the cloud-based platform for further studies. This condition will also serve as a vital reference for implementing a cloud-based platform for higher education academic platform. PTSs can practically utilize this proposed solution through both ways of government or private initiatives. The government should support by enacting favorable legislation and updated 
amendments for maintaining standards in the educational process and improvements in the related field. More business domains, business capabilities, and service functions can be applied and put inside the framework. Private sectors play their part by investing in technology's infrastructure and runs operations and management; PTSs can rent the whole infrastructure, systems, and resources monthly expenditure following their strategic plans. Some detailed technical area still needs to be provided within the design part of the cloud-based platform such as virtualization scheme, database scheme, and API management scheme. Furthermore, we will also expect a transformation of higher education institutions based on the fundamental premise that this process is an ecosystem consisting of several interlinked and interacting subsystems. Transformation must support student intrinsic motivation for learning and provide students with strategies that empower them to learn. Technology and its implementation should also move in that direction. All, in the end, is to create a systematic effort of efficient and effective learning in higher education institutions and establish a systematic approach for implementing a continuous improvement strategy in the educational process.

\section{REFERENCES}

[1] Law of the Republic of Indonesia Number 12 Year 2012 on Higher Education, no. 12. 2012.

[2] C. Marinagi, C. Skourlas, and P. Belsis, "Employing Ubiquitous Computing Devices and Technologies in the Higher Education Classroom of the Future," Procedia-Social and Behavioral Sciences, vol. 73, pp. 487-494, 2013, doi:10.1016/j.sbspro.2013.02.081.

[3] L. W. Santoso and Yulia, "Data Warehouse with Big Data Technology for Higher Education," Procedia Computer Science, vol. 124, pp. 93-99, 2017, doi:10.1016/j.procs.2017.12.134.

[4] M. Ivanović, A. K. Milićević, V. Aleksić, B. Bratić, and M. Mandić, "Experiences and perspectives of Technologyenhanced learning and teaching in higher education-Serbian case," Procedia Computer Science, vol. 126, pp. 13511359, 2018, doi:10.1016/j.procS.2018.08.086.

[5] F. N. Alfahad, "Effectiveness of Using Information Technology in Higher Education in Saudi Arabia," Procedia Social and Behavioral Sciences, vol. 46, pp. 1268-1278, 2012, doi:10.1016/j.sbspro.2012.05.287.

[6] A. Tongkaw, "Multi-perspective integrations Information and Communication Technologies (ICTs) in higher education in developing countries," Procedia-Social and Behavioral Sciences, vol. 93, no. 0, pp. 1467-1472, 2013, doi:10.1016/j.sbspro.2013.10.065.

[7] I. A. Brahmasar and H. Panjaitan, "The Influence of Using Academic Information System on Private University Image and Its Impact to Competitive Advantage," Archives of Business Research, vol. 5, no. 8, 2017, doi:10.14738/abr.58.3558.

[8] C. wen Shen and J. tsung Ho, "Technology-enhanced learning in higher education: A bibliometric analysis with latent semantic approach," Computers in Human Behavior, vol. 104, 2020, doi:10.1016/j.chb.2019.106177.

[9] A. Pangarso, "How to improve the quality of private universities, where the majority of Indonesian students study?" The Conversation, 2019.

[10] ecampuz, "4 Common Problems Building a Campus Academic Information System," eCampuz Blog, 2017.

[11] L. A. Linley, "Facing the future: a call for higher education in sleep technology," Sleep Medicine, vol. 40, pp. 124128, 2017, doi:10.1016/j.sleep.2017.09.008.

[12] H. Santos, J. Batista, and R. P. Marques, "Digital transformation in higher education: The use of communication technologies by students," Procedia Computer Science, vol. 164, pp. 123-130, 2019, doi:10.1016/j.procs.2019.12.163.

[13] Institute IT Governance, Second edition 2. 2003.

[14] T. Erl, Service-Oriented Architecture: Concepts, Technology, and Design. 2005.

[15] F. Azma, "The quality indicators of information technology in higher education," Procedia - Social and Behavioral Sciences, vol. 30, pp. 2535-2537, 2011, doi:10.1016/j.sbspro.2011.10.494.

[16] E. Hustad and C. de Lange, "Service-oriented Architecture Projects in Practice: A Study of a Shared Document Service Implementation," Procedia Technology, vol. 16, no. 2212, pp. 684-693, 2014, doi:10.1016/j.protcy.2014.10.017.

[17] Proteans, "Service-Oriented Architecture Provide Flexibility to Business Operations," White Paper, 2009.

[18] M. Moghaddam, J. R. Silva, and S. Y. Nof, "Manufacturing-as-a-Service-From e-work and service-oriented architecture to the cloud manufacturing paradigm," IFAC-PapersOnLine, vol. 28, no. 3, pp. 828-833, 2015,

[19] V. H. Pardeshi, "Cloud Computing for Higher Education Institutes: Architecture, Strategy and Recommendations for Effective Adaptation," Procedia Economics and Finance, vol. 11, no. 14, pp. 589-599, 2014, doi:10.1016/s2212-5671(14)00224-x.

[20] P. C. Santana-Mancilla, M. A. García-Ruiz, R. Acosta-Diaz, and C. U. Juárez, "Service-oriented architecture to support Mexican secondary education through mobile augmented reality," Procedia Computer Science, vol. 10, pp. 721-727, 2012, doi:10.1016/j.procs.2012.06.092.

[21] M. Mircea and A. I. Andreescu, "Service-Oriented University: Changes and opportunities towards innovation," Procedia-Social and Behavioral Sciences, vol. 31, no. 2011, pp. 251-256, 2012, doi:10.1016/j.sbspro.2011.12.051.

[22] A. N. Fajar, A. Nurcahyo, and S. R. Sriratnasari, "SOA System Architecture for Interconnected Modern Higher Education in Indonesia," Procedia Computer Science, vol. 135, pp. 354-360, 2018, doi:10.1016/j.procs.2018.08.184. 
[23] E. L. Hadisaputro, "Making International Academic Information System Architecture STMIK Borneo Using Enterprise Architecture Planning and Zachman Framework," Jurnal Sistem Informasi, vol. 1, no. 2, pp. 75-85, 2018.

[24] H. A. Mumtahana, W. W. Winarno, and A. Sunyoto, "Architectural Design of Academic Information Systems STT Dharma Iswara Madiun with the Zachman Framework," Jurnal IT CIDA, vol. 2, no. 2, pp. 14-26, 2016.

[25] A. Basir, A. Fadlil, and I. Riadi, "Enterprise Architecture Planning Academic Information System With TOGAF ADM," J-SAKTI (Jurnal Sains Komputer dan Informatika), vol. 3, no. 1, pp. 1-10, 2019, doi:10.30645/jsakti.v3i1.91.

[26] S. Jones, "A Methodology For Service Architectures A Methodology For Service Object-Oriented Design works because of an Object," Methodology, no. August, pp. 0-31, 2005.

[27] G. Rackham, "Banking Industry Architecture Network How-to Guide Semantic API," pp. 1-54, 2018.

[28] K. Peffers, T. Tuunanen, and C. Gengler, "The design science research process: a model for producing and presenting information systems research,” Journal of Management Information Systems, February, pp. 83-106, 2006.

[29] “About BIAN," BIAN, 2008.

[30] C. Matthew MacKenzie, Ken Laskey, Francis McCabe, Peter F. Brown, and Rebekah Metz, "Reference Model for Service Oriented Architecture 1.0, Committee Specification 1," no. August, pp. 1-31, 2006.

[31] M. Coccoli, A. Guercio, P. Maresca, and L. Stanganelli, "Smarter universities: A vision for the fast-changing digital era," Journal of Visual Languages and Computing, vol. 25, no. 6, pp. 1003-1011, 2014, doi:10.1016/j.jvlc.2014.09.007.

[32] I. Bongiovanni, "The least secure places in the universe? A systematic literature review on information security management in higher education," Computers and Security, vol. 86, pp. 350-357, 2019, doi:10.1016/j.cose.2019.07.003.

[33] M. F. Gholami, F. Daneshgar, G. Beydoun, and F. Rabhi, "Challenges in migrating legacy software systems to the cloud — an empirical study,” Information Systems, vol. 67, pp. 100-113, 2017, doi:10.1016/j.is.2017.03.008.

[34] F. Moreira, M. J. Ferreira, C. P. Santos, and N. Durão, "Evolution and use of mobile devices in higher education: A case study in Portuguese Higher Education Institutions between 2009/2010 and 2014/2015," Telematics and Informatics, vol. 34, no. 6, pp. 838-852, 2017, doi:10.1016/j.tele.2016.08.010.

\section{BIOGRAPHIES OF AUTHORS}

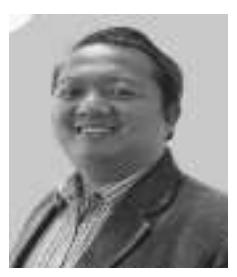

Faiza Renaldi is a lecturer in the department of informatics, Faculty of Science and Informatics, Universitas Jenderal Achmad Yani Indonesia. In 2006, He received his Master of Business Informatics at Universiteit Utrecht, The Netherlands. His research interests are health informatics, information systems/information technology management, e-government, agile project management, and IT entrepreneurship.

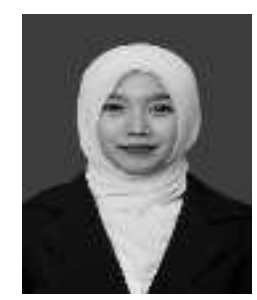

Irma Santikarama received her Bachelor's degree in Information System from Universitas Kristen Maranatha and Master's degree in Informatics from Institut Teknologi Bandung. Now, she is a lecturer in the Informatics Department, Faculty of Science and Informatics, Universitas Jenderal Achmad Yani. Her research area includes the information architecture, information management, and business process redesign.
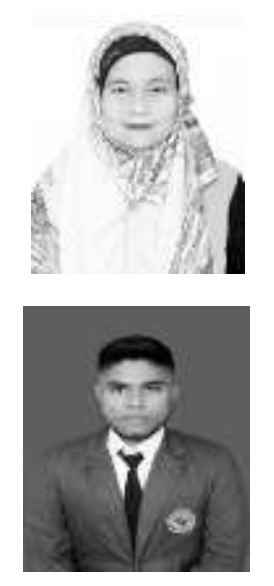

Esmeralda C Djamal received a Bachelor's degree in Engineering Physics from Institut Teknologi Bandung in 1994, a Master's degree in Instrument and Control from Institut Teknologi Bandung in 1998. She finished the doctoral program at Institut Teknologi Bandung in 2005. Now, she is a lecturer in Informatics Department, Universitas Jenderal Achmad Yani.

Agya Java Maulidin is a research assistant at informatics, Universitas Jenderal Achmad Yani, Indonesia. His primary research interests are web services technologies, NoSQL technology, and mobile-based application. 